\title{
PRIMEROS FRUTOS EN LA LUCHA CONTRA LA CORRUPCIÓN EN COSTA RICA: CONDENATORIA EN SEDE PENAL POR DELITOS TIPIFICADOS POR LA LEY CONTRA LA CORRUPCIÓN*
}

\author{
Jennifer Isabel Arroyo Chacón $n^{* *}$
}

\begin{abstract}
Resumen: El presente documento pretende analizar y compartir una de las primeras experiencias generadas en la lucha contra la corrupción en la función pública costarricense, luego de la aprobación de la Ley contra la corrupción y el enriquecimiento ilícito en la función pública en ese país. Para comprender el caso, se inicia con un segmento de antecedentes de la lucha contra la corrupción en Costa Rica, citando tanto los instrumentos jurídicos internacionales y nacionales como las instituciones sobre quienes se les ha delegado esa
\end{abstract}

* Fecha de recepción: 10 de diciembre de 2014. Fecha de modificación: 15 de octubre de 2015. Fecha de aceptación: 15 de enero de 2016. Para citar el artículo: ArRoyo ChACón, JeNNIFER IsABEL (2015). "Primeros frutos em la lucha contra la corrupción en Costa Rica: condenatoria en sede penal por delitos tipificados por la Ley contra la corrupción”, Revista Derecho Penal y Criminología, Vol. 37 , n. 101 , julio-diciembre de 2015. Bogotá: Universidad Externado de Colombia, pp. 51-86. DOI: http://dx.doi.org/10.18601/01210483.v36n101.03

** Abogada, Contadora Pública Autorizada, Auditora y Administradora Pública. Incorporada al Colegio de Abogados, Instituto de Auditores Internos y Colegio de Contadores Públicos de Costa Rica. Cursa Diplomado en Derecho Internacional de la Universidad para la Paz y posee un Diplóme d'supérieures spécialisées en Administration Publique de la Universidad de Quebec, Canadá, y una Maestría en Administración Pública con énfasis en Gestión Pública, de la Universidad de Costa Rica. Autora de libros y artículos en las ramas de su especialidad en español, inglés y portugués. San José de Costa Rica, Costa Rica. Correo-e: prof.jenniferarroyo@yahoo.com. 
función. Posteriormente, se explica la tipificación de los delitos analizados en el caso en discusión, con el fin de que el lector comprenda el marco jurídico vigente en el momento en que ocurrieron los hechos. Finalmente, se realiza un analisis profundo de la sentencia de la Sala Tercera de la Corte Suprema de Justicia que avala la condenatoria de los imputados por los delitos de corupción en la función pública, con una descripción detallada de cada tipo penal y el razonamiento jurídico expuesto por el Tribunal en su sentencia, elemento enriquecedor de la discusión de la lucha contra la corrupción en la función pública. Termina el texto destacando la importancia de este primer precedente en la lucha contra la corrupción en la función pública e invita a seguir su ejemplo.

Palabras clave: Lucha contra la corrupción; Enriquecimiento ilícito; Entidades de Fiscalización Superior; Delitos funcionales.

\title{
THE FIRST FRUITS IN THE FIGHT AGAINST CORRUPTION IN COSTA RICA: CONVICTION IN A CRIMINAL COURT FOR OFFENSES UNDER THE ACT AGAINST CORRUPTION
}

\begin{abstract}
This paper analyzes and shares one of the first experiences generated in the fight against corruption in Costa Rica after the adoption of the Law against corruption and illicit enrichment in the public service in this country. To understand the case, this paper begins with a review of corruption fighting in Costa Rica, citing international and national legal instruments and the institutions responsibility for this function. Next, it analyses the penalization for the readers to understand the existing legal framework at the time of the events. Also, this document presents the judgment of the Third Chamber of the Supreme Court, which supports the conviction of the accused of the offenses of corruption in the public service. It details each offense and the reasoning displayed by the Court in its judgment, enriching the discussion of the fight against corruption in the public service. Finally, the document highlights the importance of this first precedent in the fight against corruption in the public service and follow suit.
\end{abstract}

Keywords: Fight against corruption; Illicit enrichment; Supreme Audit Institutions; Functional crimes. 


\section{INTRODUCCIÓN}

La lucha contra la corrupción se ha convertido en uno de los objetivos principales de los gobiernos, dado que responde a una demanda de la ciudadanía y una obligación del Estado: el velar por el correcto uso y disposición de los fondos públicos.

Esta preocupación no se limita a un Estado en particular sino que ha despertado interés en toda la comunidad internacional, lo cual ha conllevado a la aprobación de instrumentos internacionales que pretenden la adopción de mecanismos internos para lograr la lucha contra la corrupción en la función pública.

Lo descrito incluye a Costa Rica, país que ha ratificado las convenciones de lucha contra la corrupción y ha emitido una ley especial para tratar este tema. Ahora bien, para visualizar los frutos de estos esfuerzos se requiere de tiempo, más allá del proceso de aprobación normativa, dado que la implementación es la fase más relevante.

El presente documento analiza un caso que se puede considerar como uno de los primeros frutos en la lucha contra la corrupción, dado que es la primera aplicación en un caso concreto de los delitos tipificados en la Ley n. ${ }^{\circ} 8422$, denominada Ley contra la Corrupción y el Enriquecimiento Ilícito en la Función Pública y luego de las reformas realizadas al Código Penal con la aprobación de esta ley.

Es una sentencia condenatoria en donde se logra sancionar tanto al funcionario público que incurrió en delitos de corrupción como al particular que participó como corruptor; se le adiciona la particularidad de originarse en una denuncia que tuvo participación activa de la Contraloría General de la República, institución a la que gracias a dichas reformas se le asignó ese destacado papel en la lucha contra la corrupción pública.

Dada la relevancia del caso, se consideró oportuno hacer un análisis al entorno en el cual se dio y un estudio detallado de los elementos que conllevaron a dicha condenatoria, como ejemplo de uno de los primeros triunfos en la lucha contra la corrupción en sede penal y un incentivo para alcanzar otras victorias en el tema.

\section{ANTECEDENTES DE LA LUCHA CONTRA LA CORRUPCIÓN EN COSTA RICA}

\section{Normas que lideran la lucha contra la corrupción en Costa Rica}

Históricamente, Costa Rica se ha caracterizado por ser un país pacífico, sin ejército y con un sistema democrático consolidado y con relativamente bajos niveles de corrupción pública. No obstante, en las últimas décadas, se denunciaron casos de corrupción que alarmaron a la opinión pública y provocaron cambios en el sistema jurídico y administrativo tendientes a luchar contra esta problemática. 
Ello llevó al país a retomar instrumentos internacionales que había ratificado anteriormente, dentro de los que se destaca la Convención Interamericana contra la Corrupción de los países miembros de la Organización de los Estados Americanos (OEA) y la Convención de las Naciones Unidas de lucha contra la corrupción, que sirvieron de guía para dar los primeros pasos en la construcción del sistema de lucha contra la corrupción en el país.

La Convención Interamericana contra la Corrupción fue suscrita en Caracas, Venezuela, en marzo de 1996, firmada por Costa Rica el 29 de marzo de 1996 y ratificada por la Asamblea Legislativa el 9 de mayo de 1997.

Esta Convención reconoce la trascendencia internacional de la corrupción y la necesidad de contar con un instrumento que promueva y facilite la cooperación entre los países para combatirla, y pretende promover y fortalecer el desarrollo, por cada uno de los Estados Parte, de los mecanismos necesarios para prevenir, detectar, sancionar y erradicar la corrupción, así como promover, facilitar y regular la cooperación entre los Estados Parte a fin de asegurar la eficacia de las medidas y acciones para prevenir, detectar, sancionar y erradicar los actos de corrupción en el ejercicio de las funciones públicas y aquellos específicamente vinculados con tal ejercicio.

La Convención establece obligaciones vinculantes dentro del marco del Derecho internacional e identifica los actos de corrupción a los que se aplicará, así como principios para combatirla eficazmente. Subraya la importancia de las medidas para prevenirla; aborda el desarrollo institucional y la aplicación efectiva de las medidas que se adopten para enfrentarla; exige la tipificación de ciertas conductas corruptas específicas, y contiene disposiciones sobre extradición, incautación de activos, asistencia jurídica recíproca y asistencia técnica en casos de corrupción que ocurran en otros Estados Parte o que los afecten.

Igualmente, posee un conjunto de medidas preventivas para disminuir la comisión de actos ilícitos en la función pública, y prevé la tipificación como delitos de determinados actos de corrupción, tales como el soborno transnacional y el enriquecimiento ilícito. Además, contiene una serie de disposiciones para fortalecer la cooperación entre sus Estados.

Por su parte, la Convención de las Naciones Unidas de lucha contra la corrupción fue firmada en la sede de la organización en Nueva York el 9 de diciembre de 2005 , y ratificada por Costa Rica mediante la Ley n. ${ }^{\circ} 8557$ del 29 de noviembre de 2006. Este instrumento constituye el más amplio acuerdo en la lucha contra la corrupción existente a nivel internacional, con más de 70 artículos, que regulan de forma extensa y puntual aspectos relacionados con la corrupción, la prevención, combate y, por supuesto, disposiciones referidas a la cooperación. Asimismo, considera las diferentes aristas del fenómeno de la corrupción, desarrolla aspectos que no estaban tratados en otras convenciones, mejora y profundiza en otros, como por ejemplo respecto a 
mecanismos de prevención, la definición de las conductas que constituyen delitos de corrupción y el tratamiento del tema de la recuperación de activos.

Lo anterior le otorga gran importancia como instrumento para el combate de la corrupción, no solo por su universalidad, sino por la forma tan completa como trata este fenómeno. Este instrumento jurídico internacional pretendía promover y fortalecer las medidas para prevenir y combatir más eficaz y eficientemente la corrupción; promover, facilitar y apoyar la cooperación internacional y la asistencia técnica en la prevención y la lucha contra la corrupción, incluida la recuperación de activos y, finalmente, promover la integridad, la obligación de rendir cuentas y la debida gestión de los asuntos y los bienes públicos.

A nivel nacional, en Costa Rica se aprueba la Ley n. ${ }^{\circ} 8422$ del 6 de octubre de 2004, Ley contra la Corrupción y el Enriquecimiento Ilícito en la Función Pública, la cual introduce en la legislación nacional, por primera vez, delitos vinculados con actos de corrupción, como: enriquecimiento ilícito, falsedad en la declaración jurada, receptación, legalización o encubrimiento de bienes, legislación o administración en provecho propio, sobreprecio irregular, falsedad en la recepción de bienes y servicios contratados, pago irregular de contratos administrativos, tráfico de influencias, prohibiciones posteriores al servicio del cargo, soborno transnacional, reconocimiento ilegal de beneficios laborales, influencia en contra de la Hacienda Pública, fraude de ley en la función administrativa, inhabilitación, violación de la privacidad de la información de las declaraciones juradas, consecuencias civiles del enriquecimiento ilícito y prescripción de la responsabilidad penal.

Concomitantemente, la Asamblea Legislativa aprobó reformar el Código Penal con el fin de alinear los delitos de: penalidad del corruptor, peculado y malversación contenidos en la legislación nacional a los tipos contenidos en los instrumentos internacionales antes citados.

\section{Instituciones encargadas de luchar contra la corrupción en Costa Rica}

Junto con las reformas legales introducidas en la legislación nacional para luchar contra la corrupción, también fue necesario delegar la labor de velar por el cumplimiento y respeto de estas normas en instituciones públicas. Para ello se reforzaron las potestades de fiscalización y control de la Contraloría General de la República, la creación de la Procuraduría de la Ética Pública dentro de la Procuraduría General de la República, y la creación de la Fiscalía Adjunta de Probidad, Transparencia y Anticorrupción dentro de la Fiscalía General de la República.

La Contraloría General de la República, órgano de fiscalización y control de la Hacienda Pública creado constitucionalmente en 1949, vio acrecentadas sus funciones y competencias al considerársele como un órgano fundamental en la lucha contra 
la corrupción, labor que ejerce tanto en sede administrativa, en ejercicio de sus potestades sancionatorias, como en sede penal en virtud de su representación judicial que le permite ser considerado actor en el proceso judicial.

La Procuraduría de la Ética Pública se creó con el fin de cumplir con las demandas de los instrumentos internacionales ratificados por el país, los cuales exigían que los países asignantes establecieran medidas preventivas de la corrupción.

Por lo tanto, esta institución tiene la función de realizar acciones para promover, detectar y erradicar la corrupción, así como incrementar la ética y la transparencia en la función pública, y para ello podrá denunciar y acusar ante los tribunales de justicia a los funcionarios públicos y las personas privadas por actos de corrupción.

Finalmente, la Fiscalía Adjunta de Probidad, Transparencia y Anticorrupción se creó con la idea de formar una fiscalía especializada en la investigación de actos de corrupción en la función pública dentro de la Fiscalía General de la República.

Esta Fiscalía Adjunta asume aquellos asuntos de todo el país que pasan un filtro de tres criterios: por la forma en que se dio el crimen (objetivo), el cargo del funcionario (subjetivo) y los efectos del hecho en la colectividad, que causen alarma o pongan en peligro la institucionalidad del país. Le corresponden, además, aquellos casos en los que figure como imputado un funcionario del Poder Judicial.

Esta Fiscalía posee la competencia de perseguir los delitos funcionales, incluida la corrupción de Jueces, Fiscales, Investigadores del Organismo de Investigación Judicial y otros funcionarios judiciales.

\section{SOBRE LA TIPIFICACIÓN PENAL DE ALGUNOS DELITOS FUNCIONALES RELEVANTES PARA LA COMPRENSIÓN DEL CASO}

Derivado de lo expuesto en el apartado anterior, se incluyeron y modernizaron delitos vinculados con actos de corrupción, de los que resulta necesario conocer su tipificación dado que fueron los sancionados en la sentencia que se analizará en el siguiente apartado.

Con el objetivo de aportarle al lector los elementos necesarios para comprender el tema, se detallan los tipos de: falsedad en la declaración jurada, enriquecimiento ilícito, cohecho impropio y cohecho impropio en la modalidad de penalidad del corruptor. El delito de falsedad en la declaración jurada se tipifica en el artículo 46 de la Ley contra la Corrupción y el Enriquecimiento Ilícito en la Función Pública, de la siguiente manera: 
Artículo 46.- Falsedad en la declaración jurada. Será reprimido con prisión de seis meses a un año, quien incurra en falsedad, simulación o encubrimiento al realizar las declaraciones juradas de bienes ante la Contraloría General de la República (Asamblea Legislativa, 1970).

Este delito pretende garantizar la correcta utilización de la declaración, pues este instrumento resulta útil en la medida en que incluya información veraz del declarante, por lo que se tipifica la falsedad, simulación o encubrimiento de bienes en el momento de rendir declaración ante el órgano contralor; por lo tanto, es un delito que puede ser cometido por acción o por omisión, con el simple hecho de no declarar la totalidad de los bienes obligados a hacerlo, siendo consciente de esa actuación irregular, requiriendo, por ende, el dolo directo para su materialización.

Finalmente, se debe señalar que es un delito especial en sentido estricto, pues solo puede ser cometido por el funcionario público que esté obligado a rendir declaración bajo los parámetros establecidos en el reglamento a la Ley contra la Corrupción y el Enriquecimiento Ilícito y lo señalado por la Contraloría General de la República.

El delito de enriquecimiento ilícito se incluyó en el ordenamiento jurídico costarricense a través del numeral 45 de la Ley contra la Corrupción y el Enriquecimiento Ilícito en la Función Pública de la siguiente forma:

Artículo 45.- Enriquecimiento ilícito. Será sancionado con prisión de tres a seis años quien, aprovechando ilegítimamente el ejercicio de la función pública o la custodia, la explotación, el uso o la administración de fondos, servicios o bienes públicos, bajo cualquier título o modalidad de gestión, por sí o por interpósita persona física o jurídica, acreciente su patrimonio, adquiera bienes, goce derechos, cancele deudas o extinga obligaciones que afecten su patrimonio o el de personas jurídicas, en cuyo capital social tenga participación ya sea directamente o por medio de otras personas jurídicas (Asamblea Legislativa, 2004).

La acción sancionada es "aprovechar ilegítimamente" el ejercicio de la función pública para hacer incrementar su patrimonio, sea aumentando los activos o bien disminuyendo los pasivos. De tal manera, estamos ante un delito de acción, pues se requiere de una actividad que conlleve al aprovechamiento del cargo público para obtener un beneficio y, a su vez, una conciencia plena de que se está actuando de manera ilegal, por lo que se requiere el dolo directo para su consumación, siendo su autor necesariamente un funcionario público.

Cuando se introdujo este numeral, la Procuraduría General de la República se pronunció respecto a este delito en los siguientes términos: 
A diferencia de lo establecido en el artículo 26 de la Ley sobre el Enriquecimiento Ilícito de los Servidores Público recién derogada, que tipificaba el delito de enriquecimiento ilícito y de lo dispuesto en el numeral $346 \mathrm{del}$ Código Penal, el artículo 45 no exige que el sujeto activo tenga la condición de funcionario público.

De acuerdo con lo anterior, cualquier persona que cometa una conducta en las circunstancias descritas en el tipo penal, podría ser considerada autor del delito de enriquecimiento ilícito. El hecho de que no se establezca el carácter de funcionario público como uno de los elementos del delito descrito en el artículo 45, se explica en el hecho de que no se pretende únicamente proteger la probidad en el ejercicio de la función pública sino la Hacienda Pública, la cual podría verse afectada también, mediante conductas cometidas por particulares bajo algunos de los supuestos descritos por la norma.

En cuanto a la acción constitutiva de la infracción, se observa que este tipo penal establece como verbo activo el acrecentar, acción que va dirigida al patrimonio del sujeto activo o el de personas jurídicas, en cuyo capital social éste tenga participación, ya sea directamente o por medio de otras personas.

Ahora bien, el artículo 45 describe otras acciones cuando señala "adquiera bienes, goce derecho, cancele deudas o extinga obligaciones", pero todas ellas estarían contenidas en la acción de "acrecentar", si se tiene en cuenta que por patrimonio se entiende la totalidad de las relaciones jurídicas de una persona respecto a los bienes de interés económico, es decir, los que son susceptibles de comercio lícito y mesurables en términos dinerarios.

Además el tipo penal, contiene otro elemento que obligatoriamente debe estar presente en la conducta cometida por el sujeto activo, para que pueda definirse su comportamiento como típico del delito de enriquecimiento. En este sentido, es preciso mencionar que el incremento en el patrimonio se debe llevar a cabo mediante el aprovechamiento ilegítimo, sea del ejercicio de la función pública o de la custodia, la explotación, el uso o la administración de fondos, servicios o bienes públicos, bajo cualquier modalidad.

Respecto a lo anterior, es importante poner énfasis en que el aprovechamiento sea del ejercicio de la función pública o de la custodia, explotación, uso o administración de fondos, servicios o bienes públicos, debe ser ilegítimo; es decir, aquel que no es conforme a lo dispuesto por ley. Así las cosas, es posible afirmar que la conducta de quien incremente su patrimonio, a través del ejercicio legítimo de la función pública o la custodia, explotación, uso o administración de fondos, servicios o bienes públicos, no sería típica y por tanto, no podría ser castigada penalmente, con base en el delito de enrique- 
cimiento ilícito tipificado en el artículo 45 de la Ley contra la Corrupción y el Enriquecimiento Ilícito (Opinión Jurídica: 107-J, 2005).

El Código Penal costarricense incluye el delito de cohecho bajo dos modalidades: cohecho propio y cohecho impropio, los cuales administran condenatoria a un particular según el principio de conmutatividad de las circunstancias.

El numeral 348 del Código Penal tipifica el cohecho propio como: "Será reprimido, con prisión de dos a seis años y con inhabilitación para el ejercicio de cargos y empleos públicos de diez a quince años, el funcionario público que por sí o por persona interpuesta, recibiere una dádiva o cualquier otra ventaja o aceptare la promesa directa o indirecta de una retribución de esa naturaleza para hacer un acto contrario a sus deberes o para no hacer o para retardar un acto propio de sus funciones" (Asamblea Legislativa, 1970).

La acción penada es recibir una dádiva, beneficio o promesa de retribución por hacer un acto contrario, o no hacer o retardar un acto propio de sus funciones; por lo tanto, este delito se puede cometer por acción, cuando se ejecuta una actuación contraria a las funciones del funcionario público, o por omisión, cuando se deja de hacer o se retrasa el cumplimiento de una obligación inherente al cargo. Esta actuación se puede realizar por acción u omisión con pleno conocimiento del actor.

El cohecho impropio se tipifica en el numeral 347 del Código Penal, de la siguiente manera: "Será reprimido con prisión de seis meses a dos años, el funcionario público que, por sí o por persona interpuesta, recibiere una dádiva o cualquier otra ventaja indebida o aceptare la promesa de una retribución de esa naturaleza para hacer un acto propio de sus funciones" (Asamblea Legislativa, 1970).

La actuación tipificada es recibir una dádiva, ventaja indebida o promesa de retribución por realizar un acto que ya se encuentra dentro de sus funciones, ejecutar labores inherentes a su cargo. Es un delito de acción, pues se refiere a recibir un beneficio, el cual no se limita a un beneficio patrimonial pudiendo ser de naturaleza diversa; por realizar algo que estaba dentro de sus funciones y obligaciones. Asimismo, se ejecuta a nivel de dolo (se requiere el dolo directo para su constitución) y solo puede ser cometido por un funcionario público que posea funciones públicas a su cargo.

En ambos casos, bajo el principio de comunicabilidad de la circunstancia, regulado en el artículo 49 del Código Penal, que permite sancionar a un particular cuando este ha cometido en conjunto con un funcionario público un delito funcional como lo son los delitos de cohecho propio y cohecho impropio, se le puede aplicar al sujeto privado que ofrece la misma normativa aplicable al funcionario público, independientemente de si este la recibe o no, o el monto o tipo de dádiva ofrecida. 


\section{ANÁLISIS DE SENTENCIA RELEVANTE DE LA SALA TERCERA DE LA CORTE SUPREMA DE JUSTICIA}

\section{Descripción de los hechos}

Los hechos ocurrieron entre los años 2003 y 2006, periodo para el cual el imputado $\mathbf{J}^{1}$ fungía como Gerente General de la Empresa [...], la cual poseía interés en abrir un relleno sanitario en una comunidad vecina del centro de San José, por lo que presentó la solicitud ante el Consejo Municipal de dicha comunidad para que se le otorgara el respectivo permiso.

Como consecuencia de esta gestión conoció al imputado MMG, quien ocupaba el cargo de Alcalde del municipio donde se pretendía colocar el relleno sanitario. Con el fin de obtener el apoyo incondicional del Alcalde MMG, el imputado J ofreció y otorgó beneficios patrimoniales a este.

El imputado MMG recientemente había perdido la casa en la cual habitaba en un proceso ejecutivo, inmueble que fue adquirido por una de las empresas que forma parte del grupo de interés económico del imputado J. y este le permitió vivir en dicho inmueble sin pagar alquiler por un periodo de veintisiete meses.

Posteriormente, le facilitó readquirir el inmueble que había perdido, y le condonó la deuda originada en la readquisición de esa propiedad en un monto de quince mil dólares.

A cambio de estos beneficios, el imputado MMG apoyó incondicionalmente el proyecto, utilizando las potestades propias de su cargo, y en su condición de Alcalde Municipal impuso veto contra el acuerdo municipal 13-94 que declaraba la existencia de la violación al derecho de expresión de los vecinos de la comunidad, porque no los convocaron a una audiencia pública para discutir la posibilidad de instalar un relleno sanitario en ese cantón.

Con el veto, el alcalde MMG indicó que no existía vicio alguno en celebrar la audiencia en el cantón, utilizando potestades que su puesto le proporcionaba, para ayudar a J ante el obstáculo que significó el acuerdo 13-94, lo que implicaba un retraso en la instalación del relleno sanitario en el cantón. También como acto propio de su función y apoyando a $\mathrm{J}$, otorga el visto bueno para el uso de suelo requerido para la elaboración del proyecto del relleno sanitario.

Por su parte, el imputado MMG, quien poseía la obligación de declarar, omitió incluir en su declaración que había perdido su propiedad en un proceso ejecutivo, y

1 Se omiten nombres en todo el texto. 
que posteriormente la adquirió mediante una deuda, omitiendo incluir el pasivo correspondiente.

Los hechos descritos originaron una investigación de parte de la Contraloría General de la República, institución que interpuso denuncia penal en 2006. En este proceso, se dictó la sentencia 31-2010 del Tribunal Penal de Juicio y la resolución 877-2011 de la Sala Tercera de la Corte Suprema de Justicia, cuyo contenido se analizará con mayor detalle en el siguiente acápite.

\section{Marco jurídico vigente en el momento en que ocurrieron los hechos}

Los hechos condenados en esta sentencia ocurrieron entre los años 2003 y 2006, por lo que se dan en un momento de transición normativa a raíz de la aprobación de la Ley contra la Corrupción y el Enriquecimiento Ilícito en la Función Pública en el año 2004 y las reformas introducidas en otros textos jurídicos, tales como el Código Penal y la Ley Orgánica de la Contraloría General de la República, que fueron aprobadas de forma concomitante.

De tal manera, se aplicaron dos leyes contra la corrupción: la n. ${ }^{\circ}$ 6872, aprobada el 17 de junio de 1983, denominada Ley Sobre el Enriquecimiento Ilícito de los Servidores Públicos, y la n. ${ }^{\circ} 8422$, denominada Ley contra la Corrupción y el Enriquecimiento Ilícito en la Función Pública, aprobada el 06 de octubre del 2004.

De la Ley n. 6872 se aplicaron varios numerales, vigentes en el momento de los hechos, que fueron:

\section{Figura 1. Normativa aplicable de la Ley contra la corrupción anterior}

\section{Ley n. ${ }^{0} 6872$ sobre enriquecimiento ilícito de los servidores públicos}

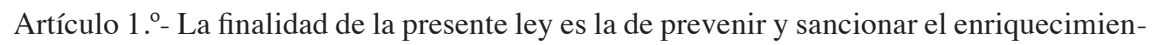
to ilícito de los servidores públicos, con el propósito de garantizar el ejercicio honrado y decoroso de la función pública.

Artículo 7. . - La Contraloría General de la República establecerá un registro de declaraciones juradas de bienes de los servidores públicos, en el cual deberá constar la declaración jurada de los bienes, renta y derechos de los funcionarios y empleados que la Constitución Política, las leyes y el ente contralor determinen como obligados a ello, conforme lo disponga el reglamento que la Contraloría deberá dictar al efecto(*). Para los fines de este artículo, el ente contralor proveerá a los servidores obligados a declarar de las fórmulas de declaración de bienes, tanto iniciales como anuales, las que tendrán el carácter de declaración jurada para todos los efectos legales. 


\section{Ley n. ${ }^{0} 6872$ sobre enriquecimiento ilícito de los servidores públicos}

Artículo 8. - La Contraloría General de la República determinará, por vía de reglamento, cuáles, rentas y derechos del servidor público deberán necesariamente ser incluidos en las fórmulas de declaración de bienes. El servidor declarante deberá indicar los bienes, rentas y derechos que constituyen su patrimonio, tanto dentro del territorio nacional como en el extranjero, en forma clara, precisa y detallada, consignado su valor. El Contralor General de la República y el Subcontralor deberán enviar copia fiel de sus declaraciones a la Asamblea Legislativa.

Artículo 12.- Todo servidor público a declarar sus bienes, deberá hacerlo ante la Contraloría General de la República dentro de los veinte días siguientes a aquél en que asuma el cargo. Para efectos de actualización del registro, también deberá presentar, en la segunda quincena del mes de mayo, una declaración anual en la fórmula correspondiente, en la que consten los bienes adquiridos durante el período, así como las mejoras de los ya declarados y las variaciones que hubiere tenido en su patrimonio, consignando el origen de los recursos y su monto.

Artículo 14.- La Contraloría General de la República podrá examinar y verificar con todo detalle la exactitud y veracidad de las declaraciones cuando lo estime oportuno, de conformidad con los procedimientos y facultades que le otorgan la Constitución Política y las leyes. En caso de detectar irregularidades que pudieran constituir delito, hará del conocimiento del Ministerio Público el estudio técnico realizado y los documentos correspondientes.

Artículo 16.- Dentro del término de un mes después de haber cesado en sus funciones, y con sujeción a los requisitos establecidos para ello, los servidores a que se refiere el artículo 7. ${ }^{\circ}$ están obligados a hacer una nueva declaración jurada de bienes, renta y derechos, en la que consignarán las variaciones que hubiere experimentado su patrimonio desde la última declaración jurada. La renuncia a cumplir con esta obligación dará lugar a que la Contraloría realice una investigación sumaria, a efecto de determinar si en las variaciones del patrimonio de ex servidor existen irregularidades que pudieran constituir delito. De ser así, el ente contralor hará del conocimiento del Ministerio Público los resultantes de esa investigación.

Artículo 27.- Será reprimido con prisión de seis meses a cuatro años e inhabilitación especial para el cargo que desempeña, por igual tiempo, todo aquel que incurriere en falsedad u ocultamiento al hacer las declaraciones ante el registro de declaraciones de bienes.

Para el análisis de las declaraciones presentadas después de 2005, se aplicó la normativa vigente, aprobada en 2004: 


\section{Figura 2. Normativa aplicable de la Ley contra la corrupción actual}

\section{Ley . $^{\circ} 8422$ contra la corrupción y el enriquecimiento ilícito en la función pública}

Artículo $1 .^{\circ}-$ Fines. Los fines de la presente Ley serán prevenir, detectar y sancionar la corrupción en el ejercicio de la función pública.

Artículo 3. - - Deber de probidad. El funcionario público estará obligado a orientar su gestión a la satisfacción del interés público. Este deber se manifestará, fundamentalmente, al identificar y atender las necesidades colectivas prioritarias, de manera planificada, regular, eficiente, continua y en condiciones de igualdad para los habitantes de la República; asimismo, al demostrar rectitud y buena fe en el ejercicio de las potestades que le confiere la ley; asegurarse de que las decisiones que adopte en cumplimiento de sus atribuciones se ajustan a la imparcialidad y a los objetivos propios de la institución en la que se desempeña y, finalmente, al administrar los recursos públicos con apego a los principios de legalidad, eficacia, economía y eficiencia, rindiendo cuentas satisfactoriamente.

Artículo 4. ${ }^{\circ}$ - Violación al deber de probidad. Sin perjuicio de las responsabilidades civiles y penales que procedan, la infracción del deber de probidad, debidamente comprobada y previa defensa, constituirá justa causa para la separación del cargo público sin responsabilidad patronal.

Artículo 21 .- Funcionarios obligados a declarar su situación patrimonial. Deberán declarar la situación patrimonial, ante la Contraloría General de la República, según lo señalan la presente ley y su reglamento, los diputados a la Asamblea Legislativa, el presidente y los vicepresidentes de la República; los ministros, con cartera o sin ella, o los funcionarios nombrados con ese rango y los viceministros; los magistrados propietarios y suplentes del Poder Judicial y del Tribunal Supremo de Elecciones; los jueces y las juezas de la República, tanto interinos como en propiedad; el contralor y el subcontralor generales de la República; el defensor y el defensor adjunto de los habitantes; el procurador general y el procurador general adjunto de la República; el fiscal general de la República; los fiscales adjuntos, los fiscales y los fiscales auxiliares del Ministerio Público; los rectores, los contralores o los subcontralores de los centros estatales de enseñanza superior; el regulador general de la República; los superintendentes de entidades financieras, de valores y de pensiones, así como los respectivos intendentes; los oficiales mayores de los ministerios; los miembros de las juntas directivas, excepto los fiscales sin derecho a voto; los presidentes ejecutivos, los gerentes, los subgerentes, los auditores o los subauditores internos, y los titulares de las proveedurías de toda la Administración Pública y de las empresas públicas, así como los regidores, los propietarios y los suplentes, y los alcaldes municipales. También, declararán su situación patrimonial los empleados de las aduanas, los empleados que tramiten licitaciones públicas, los demás funcionarios públicos que custodien, administren, fiscalicen o recauden fondos públicos, establezcan rentas o ingresos en favor del Estado; los que aprueben y autoricen erogaciones con fondos públicos, según la enumeración contenida en el reglamento de esta ley, que podrá incluir también a empleados de sujetos de derecho privado que administren, custodien o sean concesionarios de fondos, bienes y servicios públicos, quienes, en lo conducente, estarán sometidos a las disposiciones de la presente ley y su reglamento. El contralor y el subcontralor generales de la República enviarán copia fiel de sus declaraciones a la Asamblea Legislativa, la cual, respecto de estos funcionarios, gozará de las mismas facultades que esta ley asigna a la Contraloría General de la República en relación con los demás servidores públicos. 


\section{Ley $n .^{0} 8422$ contra la corrupción y el enriquecimiento ilícito en la función pública}

Artículo 22.- Presentación de las declaraciones inicial, anual y final. La declaración inicial deberá presentarse dentro de los treinta días hábiles siguientes a la fecha de nombramiento o la de declaración oficial de la elección por parte del Tribunal Supremo de Elecciones, cuando se trate de cargos de elección popular. Para efectos de actualización, también deberá presentarse cada año, dentro de los primeros quince días hábiles de mayo, una declaración en la cual se hagan constar los cambios y las variaciones en relación con la situación patrimonial declarada. Por último, dentro del plazo de los treinta días hábiles inmediatos al cese de funciones, los funcionarios públicos deberán presentar una declaración jurada final, en la cual se reflejen los cambios y las variaciones en la situación patrimonial; lo anterior según las disposiciones reglamentarias que se dicten al efecto de conformidad con esta Ley. Las declaraciones serán formuladas bajo fe de juramento.

Artículo 29.- Contenido de la declaración. Además de lo dispuesto en el Reglamento de esta Ley, el servidor público deberá incluir en su declaración, en forma clara, precisa y detallada, los bienes, las rentas, los derechos y las obligaciones que constituyen su patrimonio, tanto dentro del territorio nacional como en el extranjero; también consignará una valoración estimada en colones.

3. De los pasivos deberán indicarse todas las obligaciones pecuniarias del funcionario en las que este figure como deudor o fiador; se señalará también el número de operación, el monto original, la persona o entidad acreedora, el plazo, la cuota del último mes, el origen del pasivo y el saldo a la fecha de la declaración.

Artículo 45.- Enriquecimiento ilícito. Será sancionado con prisión de tres a seis años quien, aprovechando ilegítimamente el ejercicio de la función pública o la custodia, la explotación, el uso o la administración de fondos, servicios o bienes públicos, bajo cualquier título o modalidad de gestión, por sí o por interpósita persona física o jurídica, acreciente su patrimonio, adquiera bienes, goce derechos, cancele deudas o extinga obligaciones que afecten su patrimonio o el de personas jurídicas, en cuyo capital social tenga participación ya sea directamente o por medio de otras personas jurídicas.

Artículo 46.- Falsedad en la declaración jurada. Será reprimido con prisión de seis meses a un año, quien incurra en falsedad, simulación o encubrimiento al realizar las declaraciones juradas de bienes ante la Contraloría General de la República.

Artículo 59.- Inhabilitación. A quien incurra en los delitos señalados en esta Ley, además de la pena principal se le podrá inhabilitar para el desempeño de empleo, cargo o comisiones públicas que ejerza, incluso los de elección popular, por un período de uno a diez años. Igual pena podrá imponerse a quienes se tengan como coautores o cómplices de este delito.

Artículo 61- Consecuencias civiles del enriquecimiento ilícito. La condena judicial firme por el delito de enriquecimiento ilícito producirá la pérdida, en favor del Estado o de la entidad pública respectiva, de los bienes muebles o inmuebles, valores, dinero o derechos, obtenidos por su autor, su coautor o cómplices, como resultado directo de este delito, salvo derechos de terceros de buena fe, conforme lo determine la respectiva autoridad judicial. En el caso de bienes sujetos a inscripción en el Registro Nacional, bastará la orden judicial para que la sección respectiva del Registro proceda a trasladar el bien a las municipalidades de los cantones donde se encuentren ubicados, si se trata de inmuebles, a fin de que puedan ser usados en obras de provecho para el cantón o de beneficencia pública. Los demás bienes tendrán el destino que se determine en el Reglamento de esta Ley. La orden de inscripción o de traspaso estará exenta del pago de timbres y derechos de inscripción. 
A nivel reglamentario, se aplicaron las normas relacionadas con cada ley vigente para el momento en que ocurrieron los hechos:

\section{Figura 3. Normativa aplicable a nivel reglamentario}

Reglamento Artículo 29.- También deberán presentar declaración los funcionarios que 24885 ocupen los siguientes puestos o realicen las funciones correspondientes a dichos puestos, y que estén nombrados de conformidad con lo que se señala en el artículo 27 de este Reglamento, en los órganos y entes de la Administración Pública Descentralizada, tanto estatales como no estatales, en las Empresas Públicas y en los Órganos Desconcentrados:

V.- En las Corporaciones Municipales, Ejecutivo Director o Jefe del Departamento, Área, Oficina o Sección Financiera, Auditor Interno, Proveedor o cargo similar.

Del contenido de las declaraciones. Artículo 31.- La declaración de los bienes, rentas, derechos y obligaciones que el funcionario posea dentro y fuera del territorio nacional, se consignará de conformidad con el detalle que se indica en los siguientes artículos. Cuando corresponda, en las declaraciones anual y final, deberá señalarse la fecha de adquisición.

Artículo 40.- En cuanto a los pasivos, se deberá indicar todas las obligaciones pecunarias del funcionario, señalando el número de operación, el monto original, la persona o entidad acreedora, el plazo, la cuota del último mes, el origen del pasivo y el saldo a la fecha de la declaración.

Reglamento Artículo 82.- Constatación de veracidad de la declaración y deber de sumi32333 nistrar información. Cuando lo estime oportuno, la Contraloría General podrá realizar el estudio necesario para determinar si la información que conste en las declaraciones rendidas se encuentra completa, exacta y veraz. De advertirse alguna omisión o confusión en los datos señalados, se solicitará al declarante que la complete o aclare, dentro del término que la Contraloría General discrecionalmente señale al efecto. En la verificación a que se refiere esta disposición, la Contraloría General de la República empleará todos los medios a su alcance, para lo cual las empresas y organizaciones financieras o bancarias, nacionales o extranjeras, con las que los declarantes posean vínculos o intereses económicos o participación accionaria relevantes para los fines de la Ley, deberán facilitar sin la dilación y a plenitud, la información requerida por la Contraloría General, mediante el Contralor General o jefe de la unidad a cargo de las declaraciones juradas de la Contraloría General, estando incluso obligadas a entregar la información requerida en el formato electrónico que la Contraloría General establezca para ese efecto.

Igualmente, se aplicaron del Código Penal los artículos 1, 12, 22, 30, 45, 47, 49, 50, 51,57 incisos 1 y 2, 58, 71, 74, 76, 103 inciso 3, 110, 340 y 345; además, el artículo 14 del Código Municipal. 


\section{Sobre los delitos sancionados en la sentencia de la Sala Tercera de Costa Rica}

La sentencia 00877-2011 del 22 de julio de 2011 resulta relevante dado que confirma la primera sentencia condenatoria emitida por un Tribunal de Juicio en sede penal por los delitos de corrupción, con dos particularidades: es la primera aplicación de la Ley n. ${ }^{\circ} 8422$, denominada Ley contra la Corrupción y el Enriquecimiento Ilícito en la Función Pública, y es la primera condenatoria originada en una denuncia penal presentada por la Contraloría General de la República y en donde el órgano contralor tuvo una participación activa en el proceso, y no simplemente como colaborador u órgano técnico, como fue su papel tradicional.

Anteriormente, la que actuaba en sede judicial era la Procuraduría General de la República; no obstante, con las reformas introducidas con la citada Ley n. ${ }^{\circ} 8422$ en 2005 y la reforma del artículo 36 de la Ley Orgánica de la Contraloría General de la República en virtud de la aprobación del Código Procesal Contencioso Administrativo en 2006, se refuerza el papel de este órgano y se le permite desempeñar un rol activo en sede penal.

La Sala Tercera resolvió varios recursos presentados contra la sentencia condenatoria 31-2010, dictada a las ocho horas del 27 de enero de 2010 por el Tribunal Penal de Juicio del Segundo Circuito Judicial de San José, en los siguientes términos:

POR TANTO: De conformidad con los artículos 39, 41 y 169 de la Constitución Política, artículos 1, 12, 22, 30, 45, 47, 49, 50, 51, 57 incisos 1 y 2, 58, 71, 74, 76, 103 inciso 3, 110, 340 y 345 del Código Penal, Ley No. 6872 de 17 de junio de 1983, Sobre el Enriquecimiento Ilícito de los Servidores Públicos, artículos $1,7,8,12,14,16,27$ y su respectivo Reglamento mediante Decreto Ejecutivo No. 24885, artículos 28, 29. V, 31 y 40, Ley No 8422, Contra la Corrupción y el Enriquecimiento Ilícito en la Función Pública, artículos 1, 3, 4, 21 , 22, 29.3, 45, 46, 59 y 61, y su Reglamento No. 32333-MPJ en su artículo 82, artículo 14 del Código Municipal, artículos 360 a 367 del Código Procesal Penal, por unanimidad este tribunal resuelve declarar a $\mathrm{MMG}^{2}$ autor responsable de los siguientes delitos: 1) Tres delitos de falsedad en la declaración Jurada en perjuicio del Sano y Normal Funcionamiento de la Administración Pública y en tal carácter se le impone el tanto de SEIS MESES DE PRISIÓN por cada uno de los delitos. 2) Un delito de cohecho impropio en perjuicio de Los Deberes de la Función Pública imponiéndosele el tanto de SEIS MESES DE PRISIÓN. 3) Un delito de Enriquecimiento Ilícito en daño del Sano y Normal Funcionamiento de la Administración Pública imponiéndosele el tanto de TRES AÑOS DE PRISIÓN. Para un total de pena de prisión en aplicación de las reglas del

2 Se omiten nombres en todo el texto, se transcribe únicamente aquello que posee interés académico. 
concurso material de CINCO AÑOS DE PRISIÓN, pena ésta que deberá descontar previo abono de la preventiva sufrida en el lugar y forma que lo indiquen los respectivos reglamentos penitenciarios. Igualmente se INHABILITA a MMG en forma especial con pérdida del cargo de elección popular de Alcalde de la Municipalidad de A.... que ejerce en este momento e incapacidad para ocupar empleos, cargos o comisiones públicas, incluidos los de elección popular por el término de CUATRO AÑOS a partir de la firmeza del fallo. Se declara a J. autor responsable de un delito de cohecho impropio en la modalidad de penalidad del corruptor en perjuicio de Los Deberes de la Función Pública y en este carácter se le impone el tanto de UN AÑO DE PRISIÓN, pena que deberá descontar previo abono de la preventiva sufrida en el lugar y forma que lo determinen los respectivos reglamentos penitenciarios. Se absuelve de toda pena y responsabilidad a MMG por cuatro delitos de Falsedad en la declaración jurada en perjuicio del Sano y Normal funcionamiento de la Administración Pública que se le ha venido atribuyendo.

La sentencia 00877-2011 de las diez horas y quince minutos del 22 de julio de 2011 de la Sala Tercera de la Corte Suprema de Justicia -excepto por un tema de comiso que no es objeto de estudio en este documento- ratifica lo resuelto anteriormente cuando declara sin lugar los recursos de casación presentados en contra de dicha resolución: "Se declaran sin lugar el resto de los alegatos de los recursos de casación interpuestos. Se declaran sin lugar los recursos de casación presentados por el licenciado JJus y por el representante del Ministerio Público" (00827-2011, 2011).

A continuación, se analizarán los argumentos más relevantes que analizó la Sala para arribar a esta conclusión.

\subsection{Capacidad de la CGR de participar en un juicio penal}

Dentro de los temas alegados en los recursos de casación presentados y de interés para los efectos de este estudio, están la capacidad de la Contraloría General de la República para actuar más allá de la presentación de la respectiva denuncia. Los imputados alegaron que el órgano contralor carecía de potestad legal para actuar en juicio, lo cual no fue recibido por la Sala Tercera.

La sentencia señala que de conformidad con el artículo $16^{3}$ del Código Procesal Penal, -aun cuando este numeral señala que en el caso de los delitos contra la corrupción

3 Acción penal. La acción penal será pública o privada. Cuando sea pública, su ejercicio corresponderá al Ministerio Público, sin perjuicio de la participación que este Código concede a la víctima o a los ciudadanos. En los delitos contra la seguridad de la Nación, la tranquilidad pública, los poderes públicos, el orden constitucional, el ambiente, la zona marítimo-terrestre, la hacienda pública, los deberes de la función pública, los ilícitos tributarios y los contenidos en la Ley de aduanas, $\mathrm{n}$. 7557 de 20 de octubre de 1995; la Ley orgánica del Banco Central de Costa Rica, n. ${ }^{\circ} 7558$ de 3 de 
y el enriquecimiento ilícito se le otorga papel activo a la Procuraduría General de la República y no señala expresamente a la Contraloría General de la República- en concordancia con el numeral 35 de la Ley Orgánica de la Contraloría General de la República que fue reformado en 2006 con la aprobación del nuevo Código Procesal Contencioso Administrativo se le otorgó legitimación activa al órgano contralor.

El citado numeral 35 señala que:

\section{ARTÍCULO 35-LEGITIMACIÓN PROCESAL}

La Contraloría General de la República tendrá legitimación procesal activa para la tutela objetiva de la Hacienda Pública o de los fondos públicos sujetos a su fiscalización, de acuerdo con las normas procesales vigentes, sin perjuicio de las facultades de que gozan para el efecto la Procuraduría General de la República y cualesquier otros entes u órganos públicos.

La Contraloría General de la República podrá apersonarse como coadyuvante de la Administración Pública demandada, actora, o como "amicus curiae" en auxilio de la función jurisdiccional, según lo estime procedente, de acuerdo con el interés objetivo que hace valer, en aquellos casos en que la pretensión objeto del proceso se encuentre regulada por la normativa jurídica relativa a la Hacienda Pública.

Las autoridades judiciales que conozcan de estos procesos darán traslado a la Contraloría General de la República, para que pueda apersonarse, dentro del plazo de tres días hábiles, salvo en lo relativo a las pretensiones relacionadas con el Derecho laboral.

Dicha participación es potestativa y no afectará la integración de la litis. (Asamblea Legislativa, 1994)

Así como del artículo 36 de la citada Ley Orgánica de la Contraloría General, también reformado en 2006, en donde se le otorgan al órgano contralor las mismas garantías y facultades procesales que posee la Procuraduría General de la República, en los términos: “Artículo 36. Garantías y facultades procesales de la Contraloría. La Contraloría General de la República contará, en lo conducente, con las mismas garantías y facultades procesales asignadas por ley a la Procuraduría General de la República” (Asamblea Legislativa, 1994), se puede

noviembre de 1995, y la Ley contra el enriquecimiento ilícito de los servidores públicos, n. ${ }^{\circ} 6872$ de 17 de junio de 1983, la Procuraduría General de la República también podrá ejercer directamente esa acción, sin subordinarse a las actuaciones y decisiones del Ministerio Público. En los asuntos iniciados por acción de la Procuraduría, esta se tendrá como parte y podrá ejercer los mismos recursos que el presente Código le concede al Ministerio Público. 
inferir que la Contraloría General de la República posee la misma legitimación procesal que la Procuraduría General de la Republica para actuar en un juicio penal en los términos del numeral 16 del Código Procesal Penal antes citado.

Finalmente, la Sala Tercera indica que, de conformidad con el artículo 75 del Código Procesal Penal, la víctima puede provocar la persecución penal, adherirse a la ya iniciada por el Ministerio Público o continuar con su ejercicio, derecho que tendrá cualquier persona contra cualquier funcionario público que, en el ejercicio de su función o con ocasión de ella, haya abusado de su cargo.

La Sala Tercera declara sin lugar el reclamo en los siguientes términos:

En el caso particular, el encartado MMG fue condenado por delitos de acción pública, a saber: falsedad en la declaración jurada, cohecho impropio y enriquecimiento ilícito, con los cuales se lesionaron los deberes de la función pública y la Hacienda Pública. A tenor del ordinal 183 de la Constitución Política, la Contraloría General de la República es un órgano auxiliar de la Asamblea Legislativa en la vigilancia de la Hacienda Pública. Con respecto a esta disposición, la Sala Constitucional ha indicado: “... El concepto de vigilancia evoca, ineluctablemente, los de fiscalización, supervisión y control de todos los extremos y aspectos que comprenden la Hacienda Pública. No cabe la menor duda que el constituyente originario erigió a la Contraloría General de la República en un órgano rector de fiscalización superior de todos los aspectos que atañen a la Hacienda Pública. Esa es su competencia genérica y originaria, de modo tal que cualquier desarrollo legislativo debe conformarse con ésta para fortalecerla y extenderla en proporción con los fines propuestos y supuestos por el constituyente originario. Cualquier norma, disposición o interpretación que redunde en un cercenamiento, limitación o desnaturalización de la competencia constitucional básica y fundamental de la Contraloría General de la República-"vigilancia de la Hacienda Pública"-, resulta per se inconstitucional..." (Sala Constitucional de la Corte Suprema de Justicia, n. ${ }^{\circ}$ 2004-02199, de las 12:59 horas, del 27 de febrero de 2004). De lo expuesto se colige que, conforme la normativa vigente en nuestro país, la Contraloría General de la República estaba plenamente legitimada para constituirse en querellante en la causa examinada. Nótese que la investigación del presente proceso dio inicio producto de una denuncia presentada por dicha institución (cfr., folios 1 a 16 del Tomo I del expediente principal). El ordinal 36 de la Ley Orgánica de la Contraloría General de la República le concede a esta institución las mismas facultades que a la Procuraduría General de la República, pudiendo intervenir como querellante dentro de un proceso penal en casos como el que nos ocupa, en el que se acusó la comisión de delitos contra la Hacienda Pública y los deberes de la función pública. En todo caso, esta Sala ha podido constatar que al exponer su reclamo, el recurrente no indica en qué radica el agravio supuestamente 
ocasionado a su defendido con la intervención de la Contraloría General de la República como querellante en este proceso. Así las cosas, se declara sin lugar el reproche $(00827-2011,2011)$.

De tal manera, el órgano contralor no solo posee potestad para investigar derivada del artículo $22^{[4]}$ de su Ley Orgánica y potestad para realizar auditorías en virtud del numeral 23 de dicho texto legal, sino que, también, cuando producto de dichas investigaciones encuentre la comisión de un delito penal cometido en contra de la Hacienda Pública tiene la capacidad de presentar la denuncia penal y actuar como querellante en todo el proceso penal.

Lo expuesto refuerza el rol de lucha contra la corrupción que el marco jurídico actual le ha otorgado al órgano contralor, otorgándole potestades para desempeñar esta función de manera más efectiva.

\subsection{Prueba técnica contable}

La prueba técnica contable resultó fundamental para la resolución del presente caso, en donde se destacaron dos estudios financieros, que son: a) El rastreo del origen de los pagos y b) el análisis de la capacidad económica del acusado, que permitieron en el primer caso determinar el origen y destino de los recursos y en el segundo la imposibilidad que tenía el acusado de cubrir gastos con sus ingresos ordinarios, por lo que se requería de una fuente de ingreso no declarada.

El rastreo del origen de los pagos permitió que el Tribunal Penal acreditara el delito de cohecho impropio, pues se demostró que el dinero utilizado para la compra de la casa que el imputado MMG había perdido provenía de la empresa cuestionada, en donde no solo se conoció el origen de los fondos sino la ruta que siguió el dinero a través de cheques y diversas cuentas bancarias hasta la hora en que entró a la cuenta del ente societario [...] la cantidad girada para el pago y el medio utilizado para el mismo. Así lo reconoce el tribunal cuando trascribe el testimonio de un perito contable del órgano contralor:

... El resultado de la investigación es que pudimos obtener el origen del cheque con el que se pagó a R. la diferencia, para cancelar el resto del pago de la venta. La ruta del dinero fue un poquito larga a partir del cheque de gerencia

4 ARTÍCULO 22-POTESTAD DE INVESTIGACIÓN

La Contraloría General de la República podrá instruir sumarios administrativos o realizar investigaciones especiales de oficio, a petición de un sujeto pasivo o de cualquier interesado. / La Contraloría General de la República también deberá instruir sumarios o realizará investigaciones especiales, cuando lo soliciten los órganos parlamentarios de la Asamblea Legislativa o cuando lo soliciten conjuntamente al menos cinco diputados. 
600-8 con el que se canceló, este salió de una cuenta transitoria del Scotia Bank, como es un cheque de gerencia el banco se asegura que el dinero deje un rastro hacia atrás, y nos dio la cuenta número [...] a nombre de Corporación [...] . Los fondos llegaron a esa cuenta corriente de una transferencia del banco Banex que provenía de [...] el 19 de agosto del 2003. El banco Banex recibe instrucción para que acredite \$60.000.00, y una vez que estén acreditados se transfieran a la cuenta del [...] en el Scotia Bank y éste recibe instrucción para que se emita un cheque de gerencia. Banex recibe instrucción de trasladar $\$ 60.000 .00$, y a su vez de éstos se trasladan 13.500 .000 colones por el cheque de gerencia...", continúa la testigo “... De acuerdo con los documentos en colilla del cheque de folio 35 del expediente de la Contraloría, el banco se respalda que tomaron el dinero y que lo trasladaron a la cuenta del Soctia (sic) Bank. En esta colilla dice autorizado por J. Cuando hago el estudio del origen de los recursos me tomo el tiempo para ver cuál era el movimiento en la cuenta hacia atrás, estudio desde mayo hasta diciembre del 2003, meses antes y después que sale el cheque 600-8, porque el dinero es difícil identificarlo cuando ha habido más dinero en esa cuenta. Verifico que en julio del 2003 en la cuenta del Scotia Bank no hay montos significativos, el promedio era entre $\$ 1.000$ y $\$ 5.000$, son montos pequeños que nunca superaban esta última cifra. Para agosto del 2003 arranca con $\$ 3.000 .00$, y al ser las 11:38 de este 22 de agosto del 2003, se trasnsfieren (sic) \$ 59.990 .00 por parte de la empresa [...]. El banco Scotia Bank emite el cheque de gerencia 600-8, debita los $\$ 33.000 .00$ que equivalen a los 13.500 .00 colones, y deja el saldo por $\$ 27.000 .00$ en la cuenta, que todavía para diciembre había quedado saldo en esa cuenta... (00827-2011, 2011).

De esta manera, el Tribunal de Juicio acredita que, gracias a este estudio de origen de los fondos que la Empresa [...], la cual poseía un interés de establecer un relleno sanitario en la comunidad en donde el imputado MMG fungía como Alcalde Municipal y ya había iniciado gestiones ante el Consejo Municipal para la aprobación de dicho proyecto de parte de esta corporación municipal, poseía un interés directo en pagarle al imputado MMG la casa que este había perdido en virtud de un remate y obtener de él el apoyo y favorecimiento para la aprobación de su solicitud de instalación del dicho vertedero en esa comunidad.

Esta conclusión se refuerza con el análisis de la capacidad económica del acusado, en donde el órgano contralor a través de su perito contable logra demostrar que en el momento en que ocurrieron los hechos el imputado MMG carecía de la capacidad económica para realizar el pago de $\$ 15.000,00$ de la deuda que poseía y, por lo tanto, estos recursos provenían de una fuente externa a sus ingresos ordinarios, como lo era la citada Empresa [...]. 
Asimismo, este estudio de capacidad económica permitió demostrar la materialización del delito de enriquecimiento ilícito, pues con ello se acrecentó el patrimonio del imputado MMG.

Existe un estudio del detalle de salarios y auditoría de MMG por parte de la División de Fiscalización Operativa y Evaluativa, Area (sic) de Denuncias y Declaraciones Juradas de la Contraloría General de la República de folios 75 a 83 del expediente respectivo de este ente contralor que concluye: De conformidad con los montos percibidos por MMG por concepto de salario, diferencias salariales, aguinaldo y salario escolar, durante el período del 26 de setiembre del 2005 al 02 de mayo del 2006 con relación a los gastos y pasivos que presuntamente debió cancelar en ese mismo período, el saldo líquido final que pudo dispones fue de 5.933.591.95 (Cinco millones novecientos treinta y tres mil quinientos noventa y un colones con noventa y cinco céntimos) (...) Ergo, unido a lo supra expuesto con respecto al estudio practicado por el equipo de investigación de la Contraloría General de la República en relación con la precaria situación económica de MG, hace que este Tribunal no de credibilidad alguna -como se dijo- a ninguno de tales presuntos recibos de pago y por contrario considere que cuando J. emite la nota indicando el saldo de la deuda subsistente con MG (sic), así como cuando se realiza el ulterior traspaso constituyéndose la hipoteca a favor de la Mutual Alajuela de Ahorro y Préstamos, hubo una condonación vedada e ilegítma (sic) de parte del señor J. en su carácter personal y como representante de sus empresas [...] , gracias a lo cual MG, como funcionario Público acrecentó su patrimonio incurriendo en la figura de enriquecimiento Ilícito que prevé el artículo 45 de la ley 8422. A partir del análisis de la prueba documental y testimonial, se desvirtúan las declaraciones dadas por los imputados al Tribunal en el debate...

Argumento aceptado por la Sala Tercera cuando en la sentencia indicó: "Asimismo, se le otorgó importancia a un estudio realizado por la Contraloría General de la República, según el cual para el momento en que supuestamente Mario canceló los quince mil dólares de la deuda de cuarenta y cinco mil dólares que mantenía con la sociedad anónima [...], no tenía capacidad económica para liquidar dicho monto, por cuanto el único ingreso que tenía para esa época provenía de su salario como Alcalde del Cantón de A...(destacado fuera del original). Con base en lo expuesto, se rechazan los reclamos".

Incluso se podría afirmar que sin el estudio técnico contable no hubiera sido posible la demostración de los delitos condenados en esta sentencia. Este tipo de estudios resultan básicos en la investigación y demostración de los delitos de corrupción, pues permiten evidenciar que un funcionario público está recibiendo fondos de fuentes distintas a sus ingresos ordinarios. Ahora bien, la capacidad económica de un funcionario no es en sí misma una prueba directa de la comisión de un acto de corrupción, pero sí constituye prueba indiciaria que unida a otros elementos de la 
investigación pueden convencer al juez de la comisión de un acto de corrupción, como es el caso que nos ocupa.

Asimismo, el auditor debe tener presente que la evidencia de auditoría, con la que comúnmente trabaja, posee diferencias importantes respecto a la prueba que será aportada en juicio, dado que esta última debe cumplir con requisitos de legalidad y objetividad aún más estrictos, dada la importancia de la misma. En el caso expuesto, los peritos que participaron en el proceso de investigación demostraron una alta calidad profesional que permitió que su trabajo fuese recibido en juicio por el Tribunal sin cuestionamiento alguno.

Lo anterior es evidencia del papel predominante del perito contable tanto en la investigación como en la demostración de un delito funcional, principalmente aquellos que poseen repercusiones económicas en la Hacienda Pública; acá no solo en términos de cuantificar un daño civil o pérdida patrimonial, sino también en la elaboración de prueba técnica tendiente a demostrar la comisión de un delito.

\subsection{Falsedad en la declaración jurada en perjuicio del sano y normal funcionamiento de la Administración Pública}

La declaración jurada de bienes es un mecanismo preventivo de lucha contra la corupción en la función pública impulsada por la Convención Interamericana contra la Corrupción de los países miembros de la Organización de Estados Americanos, particularmente en el inciso 4) del Artículo III, denominado Medidas Preventivas, cuando dice: "4. Sistemas para la declaración de los ingresos, activos y pasivos por parte de las personas que desempeñan funciones públicas en los cargos que establezca la ley y para la publicación de tales declaraciones cuando corresponda" (Organización de Estados Americanos - OEA, 1996).

Este mecanismo preventivo debe ir acompañado de un sistema sancionatorio que garantice su cumplimiento y sirva como un instrumento para detectar posibles inhabilidades e incompatibilidades en los procesos de contratación pública o para gestionar asuntos después del retiro del funcionario, así evitar situaciones que contengan conflictos de intereses; ya que si bien podría ser útil como condición para que un funcionario pudiera posesionarse en un determinado cargo, podría restringir el acceso a la función pública a ciertos empresarios privados.

La Convención es clara al indicar que se deben incluir no solo los activos sino también los pasivos del declarante para tener la información de la situación patrimonial del funcionario público de forma completa. Asimismo, demanda que debe existir un ente estatal con el deber y competencia de verificar la veracidad de la información contenida en dicha declaración y sirva como un indicio para detectar la posible comisión de un delito de enriquecimiento ilícito en la función pública, de tal manera que se instauren las investigaciones correspondientes y poder determinar la verdad 
de los hechos y si el beneficio en el patrimonio -incremento sea por adquisición de bienes o disminución de pérdidas-, se debe efectivamente a la comisión de un delito.

Se estableció la obligación de los países que han ratificado esta Convención de adoptar la normativa interna para que se cumpla con este mecanismo de control.

Costa Rica, como país adherente a dicha Convención, incluyó, en los términos requeridos por este instrumento, la declaración jurada de bienes en la función pública, en la Ley n. ${ }^{\circ} 8422$, en donde se señala a la Contraloría General de la República como el ente responsable de recibir, custodiar e investigar la declaración jurada de bienes, y se establecieron los bienes a declarar.

Para efectos de este estudio, resulta relevante destacar la obligación del declarante de incluir en su declaración sus activos, pero también los pasivos que posee el funcionario público obligado a declarar toda vez que el beneficio patrimonial dado a un funcionario por la comisión de un delito en virtud de su cargo se puede dar no solo otorgándole una regalía, un pago, un activo que incremente su patrimonio de forma directa sino, también, contribuyendo a disminuir los pasivos que este tenga, sea condonándole una deuda, asumiendo una deuda que poseía o cancelando un pasivo, con lo cual hay un incremento patrimonial de forma indirecta, de tal manera que la omisión de declarar un pasivo puede ser utilizada para ocultar la comisión de un ilícito.

Este fue el razonamiento dado por el Tribunal de Juicio en el presente caso, en donde consideró que la declaración falsa dada por el imputado era una manera de ocultar el enriquecimiento ilícito.

... Vemos como el señor Alcalde MMG declara falsamente en las declaraciones juradas no cualquier acto sino actos relacionados con la propiedad No [...] y que precisamente lo vinculan directamente con el co-imputado J. en su condición de apoderado de Corporación [...] S.A. No solo (sic) contamos con prueba documental, la cual ya ha sido suficientemente analizada, sino con prueba testimonial, así las declaraciones de H. en su condición de fiscalizadora contable de la Contraloría General de la República, la que en relación a este tema declaró: “... En el año 2006 preciso julio, salió una publicación en el Periódico La Nación donde sale en la primera página que el gerente de la Empresa [...] financia la casa del Alcalde de A... A partir de allí el jefe de área, Lic. JB toma el recorte de periódico y me es asignado número de caso para que verifique los sistemas y documentos sobre el caso. La Contraloría General de la República cuenta con las declariones (sic) juradas de los funcionarios públicos que están obligados a declarar y que es el instrumento para detectar los delitos de corrupción. Como primer instrumento nos fuimos a ver si el inmueble se refería a la casa del partido de San José. Verificados en las declaraciones juradas de MM vimos que dicho inmueble había tenido varios movimientos registrales del año 2001 al 2005 que no se habían reflejado en las 
declaraciones... Los pasivos de acuerdo con la Ley contra el Enriquecimiento Ilícito se deben rendir en la declaración jurada y deben declararse, que son las deudas, todo lo que implique una erogación a una tercera persona, es lo que sobre los bienes implica una deuda. Desde que la ley se promulgó una de las razones es que la declaración sea una fotocopia de la situación patrimonial, una transcripción de todo el patrimonio de lo que tengo como de lo que debo...

Continúa el análisis del Tribunal de Juicio indicando que no existió justificación jurídica válida para omisión presentada en la declaración del imputado.

Derivado de lo anterior se desvirtúa la explicación que el imputado MMG da en el debate, porque de la simple lectura del formulario de las declaraciones juradas de la Contraloría General de la República, se desprende que las casillas que se deben llenar, no solo son claras, sino que de manera expresa hay un ítem exclusivo para los pasivos, sin que permita inducir en error al declarante en el momento de llenar el formulario, de tal forma que la simple indicación de la existencia de una variación en un bien inmueble que ya no le pertenece y sin explicar en qué consiste esa variación, nunca puede justificar la omisión de exponer la existencia de pasivos o bien que la propiedad que declara como suya no lo era en dos de las declaraciones que así lo hizo. El imputado Morales Guzmán es un abogado, cuya experiencia en la administración pública, específicamente como Alcalde de A... le permiten tener conocimiento no sólo de las consecuencias legales de declarar hechos falsos ante el ente Contralor, sino de conocer el término contable "pasivo", máxime que administra el Gobierno local de A... En consecuencia, no existe justificación alguna que le exima de responsabilidad a Morales Guzmán, porque su profesión y trabajo le permiten conocer los términos que solicita la Contraloría General de la República en las declaraciones juradas, formularios que están descritos con suma claridad, sin que se permita el error, aunado al conocimiento de las consecuencias legales de una declaración falsa, sin que pueda tratarse como términos equivalentes una variación en el inmueble a su pérdida definitiva, y menos aún a declarar como suyo algo que no le pertenece. Como se indicó el 22 de mayo del 2006 declaró no poseer pasivos (folio 188), siendo que el 3 de mayo de 2006 adquirió el crédito con la Mutual Alajuela. No es posible que olvide en un tiempo tan corto, DIECINUEVE DIAS, la obligación de consignar este pasivo... (cfr., folios 1282 a 1284). (00827-2011, 2011).

Se debe destacar la importancia que el Tribunal le otorga a esta omisión, que no puede considerarse como un "simple olvido", agravado por el hecho de que el imputado sea abogado y con amplia experiencia en la administración pública, de tal manera que no se le puede considerar como un simple descuido o una falta administrativa, o bien, un desconocimiento de la ley vigente, por el contrario refleja un actuar deliberado del acusado, con una clara intención de omitir información patrimonial relevante. 
Por ende, la violación a este mecanismo preventivo, tal y como lo requirió la Convención Interamericana, va acompañada de un régimen sancionatorio, tanto en sede administrativa como en sede penal con la tipificación del delito.

Ahora bien, respecto a la declaración de bienes propiamente dicha, el imputado MMG, en su condición de Alcalde municipal, estaba obligado a rendir declaración jurada de forma completa, es decir, incluyendo todos los aspectos enlistados en el artículo 29. No obstante, de manera consciente y reiterada, omitió declarar la pérdida de su vivienda y el pasivo que recaía en ella; es decir, incurrió en falsedad al no declarar sus pasivos. Así lo afirma la sentencia en estudio:

En el fallo se indica que MMG no declaró la pérdida de su vivienda, así como tampoco reportó un pasivo que pesaba sobre ésta una vez que la readquirió. Se dice que la profesión y el trabajo de MMG, le permitía conocer los términos que la Contraloría General de la República le solicitaba en las declaraciones juradas, así como también, las consecuencias del incumplimiento de las exigencias legales (00827-2011, 2011).

En consecuencia, no se trata de una simple omisión a un deber formal, como lo quiso hacer ver el imputado, sino que se refiere a un delito cometido en contra de la declaración jurada de bienes como instrumento preventivo de lucha contra la corrupción instaurada por la Convención Interamericana e integrada a la legislación nacional con la Ley contra la corrupción. En consecuencia, es un delito cometido en contra del deber de probidad, principio rector de la función pública. En estos términos se realiza la valoración del delito tipificado y se sanciona al imputado por el delito de falsedad ideológica al omitir sus pasivos y, por lo tanto, presentar tres declaraciones falsas ante el órgano contralor.

Finalmente, en lo que respecta al tema del bien jurídico, se aprecia que el Tribunal estableció claramente cómo M, al presentar tres declaraciones juradas falsas ante la Contraloría, lesionó el deber de probidad que debía guardar en el ejercicio del cargo de Alcalde que ostentaba, revelando su interés delictivo de omitir su situación real, ocultando su mala situación económica. La probidad en la función pública implica rectitud y honestidad de los funcionarios públicos en el ejercicio de sus labores, dentro de lo que se incluye por supuesto el rendir cuentas de forma satisfactoria, es decir, ajustadas a la verdad, lo cual no hizo MMG. Así las cosas, al no estar en presencia de los vicios señalados, se declaran sin lugar los reclamos (00827-2011, 2011).

Lo expuesto conlleva al Tribunal de Juicio a condenar al imputado por tres delitos de falsedad en la declaración jurada de bienes en perjuicio del sano y normal funcionamiento de la Administración Pública, condenatoria confirmada en casación. Se destaca dicha condenatoria dado que refuerza el papel de la declaración jurada de bienes como un mecanismo preventivo en la lucha contra la corrupción en la función 
pública, y le otorga una importancia más allá de un simple requerimiento o documento que se deba llenar para cumplir con un requisito administrativo más, además de reforzar la potestad que posee el órgano contralor de investigar el contenido de este instrumento y utilizarlo como un medio para detectar actos de corrupción en la función pública.

\subsection{Enriquecimiento ilícito y cohecho impropio}

En el caso en estudio, el Tribunal de Juicio condenó al imputado por el delito de enriquecimiento ilícito en la función pública tipificado en el artículo 45 de la Ley n. ${ }^{\circ} 8422$, denominada Ley contra la Corrupción y el Enriquecimiento Ilícito de la Función Pública, y el delito de cohecho impropio se tipifica en el Código Penal.

El delito de enriquecimiento ilícito se acreditó cuando el imputado MMG aprovechó su cargo como funcionario público para acrecentar su patrimonio adquiriendo un bien que anteriormente había perdido, cancelando además parcialmente la deuda que tenía para con el coimputado J. y sus empresas.

Contrario a lo expuesto por el defensor particular de MMG, en el fallo se explica claramente la tipicidad del delito de enriquecimiento ilícito tanto desde el punto de vista subjetivo como objetivo. Al respecto se apunta: “... En el presente caso resulta claramente acreditado, conforme al análisis que se hace en el considerando de fondo que el imputado MMG, aprovechando ilegítimamente el ejercicio de la función pública, por sí, acrecentó su patrimonio, lo que hizo al mismo momento en que adquirió el bien que anteriormente había perdido, gozando así nuevamente del derecho de propiedad que había perdido tiempo atrás, cancelando además parcialmente la deuda que tenía para con el coimputado J. y sus empresas, misma que afectaba su patrimonio, el que además, reiteramos, se vio acrecentado de manera ilegítima en la suma de quince mil dólares dichos. En consecuencia, la adecuación típica en el delito referido resulta perfecta, se trata además un delito doloso en el cual el tipo subjetivo se configura por el correlativo conocimiento y voluntad de realizar el tipo objetivo, en los términos dichos. En efecto, este delito se configura, cuando J. emite la nota indicando el saldo de la deuda subsistente con MMG, quien la emplea -lo que le permite adquirir una propiedad (la número [...] del Partido de San José) que tenía un valor mayor, para la cual MMG no tenía soporte económico en sus ingresos para acceder al crédito hipotecario de la Mutual, de modo que se le aprobara el crédito por la totalidad del valor de la propiedad, ni condición económica que le hubiera permitido asumir la deuda por la totalidad del valor de la propiedad- así como cuando se realiza el ulterior traspaso constituyéndose la hipoteca a favor de la Mutual Alajuela de Ahorro y Préstamo, momento en el cual hubo una condonación vedada e ilegítima (sic) de parte del señor J. en su carácter personal y como represen- 
tante de sus empresas [...], gracias a lo cual MMG, como funcionario Público acrecentó su patrimonio incurriendo en la figura de enriquecimiento Ilícito..." (cfr., folios 1316 a 1317). De lo trascrito se constata que la sentencia expone debidamente la forma en que el endilgado acrecentó su patrimonio aprovechando ilegítimamente su cargo dentro de la función pública. Así las cosas, se rechaza el reclamo planteado (00827-2011, 2011).

Continúa el tribunal señalando que la condonación de la deuda por quince mil dólares forma parte del enriquecimiento ilícito.

Con respecto al delito de enriquecimiento ilícito, los juzgadores destacaron: “...Posteriormente en escritura número ochenta del notario José Carlos Quesada Camacho, se cancela hipoteca a favor de [...] y se constituye hipoteca a favor de Mutual Alajuela por la suma de 16 millones de colones. Mutual Alajuela paga a [...] 15.270.000 colones, en fecha 3 de mayo del año 2006 (ver escritura número ochenta a folios 1 a 6 del Expediente Mutual Alajuela de Ahorro y Préstamo y cheque a folio 14 en que el Banco Nacional, mediante cheque 5218-4 de 3/5/06, paga a la orden de [...] S.A de la cuenta de Mutual Alajuela de Ahorro y Préstamo dicha suma la suma de quince millones doscientos setenta mil colones). Ahora, el crédito que gestionó MORALES GUZMAN a la Mutual de Alajuela para cancelar la hipoteca a [...] S.A tenía el inconveniente de que tan solo cubriría $\$ 30.000 .00$ y no los $\$ 45.000 .00$ adeudados. Es por ello que J.mediante nota $N^{\circ} G G$-TV/209 de 7 de abril de 2006 dirigida a Mutual Alajuela, y en su condición de Presidente y Apoderado Generalísimo de [...] S.A suscribe: “... Que el señor Mario Morales Guzmán sostiene hipoteca en primer grado a favor de mi representada por un monto original de USA 45.000.00 (cuarenta y cinco mil dólares estadounidenses). Que a la fecha el monto del principal adeudado es por la suma de USA 30.000 .00 (treinta mil dólares exactos) y se encuentra al día por concepto de intereses." (Ver folio 71 del Exp. Mutual Alajuela...). Es así como J. condona quince mil dólares a MORALES GUZMAN y ajusta la deuda al monto que si financiaría la Mutual e indica que el deudor se encuentra al día en el pago de intereses. Por esto MORALES GUZMAN aprovechándose ilegítimamente de su puesto de Alcalde de A... acrecentó su patrimonio en la suma de \$15.000.00, y por ello adecuando su conducta al tipo penal de Enriquecimiento Ilícito tipificado en el artículo 45 de la Ley 8422, que prescribe que será sancionado con prisión de tres a seis años quien, aprovechando ilegítimamente el ejercicio de la función pública..., acreciente su patrimonio..." (cfr., folios 1297 a 1298, el subrayado no es del original). Se aprecia sin mayor dificultad que fue producto de la nota GG-TV/209 dirigida a Mutual Alajuela -en la que se indicó que Mario Morales había cancelado quince mil dólares a J - que la entidad bancaria accedió al crédito solicitado por Mario, operando una condonación de quince mil dólares a favor de Morales. Se tiene que el delito de enriquecimiento ilícito data del año 2006, por lo que bajo estas circunstancias se aplicó correctamente el 
artículo 45 de la Ley contra la Corrupción y el Enriquecimiento Ilícito en la Función Pública, publicada en el Diario Oficial La Gaceta el 29 de octubre de 2004 (00827-2011, 2011).

Ahora bien, el delito de cohecho impropio se dio por acreditado cuando el imputado MMG pretendió utilizar su cargo en beneficio de un tercero para recibir una dádiva, la cual consistió en usufructuar la vivienda que había perdido en un proceso ejecutivo anterior.

En los hechos constitutivos del delito de cohecho impropio la finalidad era beneficiar a la empresa [...] mediante actos propios de su cargo a cambio de recibir dádivas (vivir gratuitamente en la vivienda que había perdido en el proceso ejecutivo y readquirir la misma en un momento posterior). En cambio, al aceptar los efectos de la nota condonatoria de quince mil dólares formulada por J. como representante de [...], su finalidad era poder aumentar el patrimonio en dicha suma, y, de esta forma, acceder a un crédito bancario para cancelar a [...] el arrendamiento comercial por cuarenta y cinco mil dólares que le había otorgado $(00827-2011,2011)$.

De tal forma que el imputado vio acrecentado su patrimonio de diversas maneras, al readquirir la propiedad que había perdido y al condonársele la deuda por 15 mil dólares, así como al usufructuar un inmueble por veintisiete meses que ya no era de su propiedad. Los dos primeros beneficios constituyen el delito de enriquecimiento ilícito y el último el de cohecho impropio.

\subsection{Cohecho impropio en la modalidad de penalidad del corruptor}

En todo acto de corrupción existen dos actores: el funcionario público corrupto y el privado corruptor, ambos indispensables para la comisión del delito, pues no solo comete falta el funcionario público que accede a utilizar su cargo para llevar a cabo una acción ilegal que beneficia los intereses particulares, sino también el privado que a cambio de recibir dicho beneficio ofrece y paga una dádiva al funcionario público corrupto.

Por ello, existen delitos funcionales que pueden ser condenados en la modalidad de corruptor, tales como el delito de cohecho impropio: "Será reprimido con prisión de seis meses a dos años el funcionario público que, por sí o por persona interpuesta, recibiere una dádiva o cualquier otra ventaja indebida o aceptare la promesa de una retribución de esa naturaleza para hacer un acto propio de sus funciones" (Asamblea Legislativa, 1970).

En el caso que nos ocupa, el Tribunal de Juicio tuvo por demostrado que el señor J, en su calidad de Gerente General de la Empresa [...] gestionó ante una corpora- 
ción municipal un permiso para construir un relleno sanitario en ese cantón, por lo que conoció al imputado MMG, quien ocupaba el cargo de Alcalde Municipal. En ese momento, se origina la relación tendiente a la comisión del acto de corrupción sancionado.

El señor $\mathbf{J}$, con el fin de adquirir el apoyo incondicional del Alcalde al proyecto de interés de su representada, le otorga dádivas y regalías tales como adquirir la casa que el imputado MMG había perdido en remate ejecutivo, permitiéndole vivir en dicha propiedad durante veintisiete meses sin pagar ningún monto de alquiler, permitiéndole readquirir esa propiedad posteriormente y condonándole la deuda en un monto de quince mil dólares.

Así lo tuvo por acreditada la sentencia:

Luego, el día 12 de junio del año 2003, el imputado J. actuando como Apoderado Generalísimo Sin Límite de Suma de Corporación [... ] procede con la única intención de obtener un apoyo incondicional en su proyecto, que gestionaba ante la Municipalidad de San José por medio de la empresa [...] a otorgar una regalía a MMG a sabiendas de su calidad de funcionario público por ser el Alcalde de A..., contactando a R, dueño registral de la finca del partido de San José matrícula folio real [...] y formaliza opción de compra venta privada sobre dicho inmueble por la suma de dieciséis millones de colones, opción a setenta días que vencía el 21 de agosto del dos mil tres, entregándole en el acto a R. la suma de dos millones quinientos mil colones. Posteriormente, en fecha 19 de agosto del año 2003, el imputado J. en Representación de la empresa [...] de Costa Rica, solicitó a Banco BANEX un crédito por SESENTA MIL DOLARES, e instruyó que una vez realizado el desembolso se transfieran esos fondos a la cuenta corriente en dólares número [...] en Scotiabank a nombre de Corporación [...] s.A., empresa que firmó la opción de compra, dándose asî contenido económico al cheque 600-8 que cancelaría la compra de la propiedad matrícula de folio real $n .^{\circ}$ [...] del Partido San José a R. En fecha 22 de agosto de ese mismo año 2003, a solicitud de J. se realiza el desembolso y la transferencia de los SESENTA MIL DÓLARES a la cuenta corriente número [...] a nombre de Corporación [...] S.A, y Scotiabank emite el cheque de Gerencia número 600-8 por la suma de TRECE MILLONES QUINIENTOS MIL COLONES, cancelándose el saldo que se adeudaba a R. por la compra del inmueble de MMG. La compra se formalizó mediante escritura número ciento treinta y cuatro de las 15 horas del 22 de agosto del 2003 y ante la notaria MVV, traspasándose así la propiedad de R. a Corporación [...] S.A.- Esta compra realizada por la empresa Corporación [...] S.A. representada por J, fue con la única intención de otorgar regalía y favorecer a $M M G$, quien había perdido su casa por no pagar un préstamo personal, y para ocultar lo ilícito de la negociación, la escritura de venta número ciento treinta y cuatro ante la notaria pública Marlene Villalobos NO FUE PRESENTADA AL REGISTRO Y POR LO TANTO NO FUE 
INSCRITA. El testimonio de escritura quedó en poder de J. pero MMG entró en posesión y disfrute del inmueble sin pagar renta e intereses, generándose un incremento indebido en su patrimonio desde el 12 de junio de 2003 (opción de compra venta por parte de J, folio 1 a 2) hasta el 26 de setiembre del año 2005 (Fecha en que R. rescinde la primera venta a Corporación [...] y vende directamente a MMG con hipoteca a favor de [...] cuyo representante es J), resultando favorecido de nuevo en su condición de funcionario público al facilitársele por J. la re-adquisición de la propiedad (ver folio 49).

Las anteriores regalías fueron dadas por el imputado $\mathbf{J}$ a cambio del apoyo incondicional del imputado MMG con su proyecto de la construcción del relleno sanitario a cambio de que este utilizara su cargo como Alcalde para apoyarlo. Dicho apoyo consistió en el veto puesto por el Alcalde contra el acuerdo municipal 13-94, que declaraba la existencia de la violación al derecho de expresión de los vecinos de la comunidad, porque no los convocaron a una audiencia pública para discutir la posibilidad de instalar un relleno sanitario en ese cantón, con el veto, señala el alcalde MMG indicó que no existía vicio alguno en celebrar la audiencia en el cantón, utilizando potestades que su puesto le proporcionaba, para ayudar a J, ante el obstáculo que significó el acuerdo 13-94, lo que implicaba un retraso en la instalación del relleno sanitario en el Cantón. También como acto propio de su función y apoyando a J otorga el visto bueno uso de suelo requerido para la elaboración del proyecto del relleno sanitario.

Por lo que el Tribunal tuvo por acreditada la participación activa del Gerente General J, corrompiendo al Alcalde para que este utilizara su cargo y favoreciera sus intereses particulares, constituyendo el delito de cohecho impropio en la modalidad de corruptor. Al respecto, dice:

En el presente caso se logró comprobar que el encartado J. al cometer el delito de cohecho impropio en la modalidad de penalidad del corruptor actuó dolosamente, ello a partir de los siguientes elementos indiciarios: $i$ ) MMG perdió la casa en remate; ii) J. compró el bien pocos meses después y nunca inscribió la escritura; iii) Los dineros utilizados para comprar el bien provenían de la empresa [...] que tenía interés de instaurar un relleno sanitario en A...; iv) MMG vivió en el bien varios meses sin pagar monto alguno de alquiler; $v$ ) MMG presentó el veto el 9 de febrero de 2004 (con posterioridad a la entrega de la dádiva del 12 de junio de 2003) indicando que no se violentaba el derecho de participación de la población de A... cuando no era así; vi) MMG otorgó visto bueno de uso de suelo a la empresa [...] (con posterioridad a la entrega de la dádiva del 12 de junio de 2003); vii) MMG readquirió la propiedad; viii) MMG nunca reportó la pérdida y readquisición del bien ante la Contraloría General de la República. En consecuencia, al no estarse en presencia de los vicios señalados, se declara sin lugar el reclamo (00827-2011, 2011). 
De tal manera que estamos ante un claro caso de penalidad de corrupción, y de la aplicación del principio de comunicabilidad de las circunstancias, descrito anteriormente.

La presente sentencia resulta relevante pues tradicionalmente se analiza la corrupción desde la óptica del funcionario público corrupto, pero para que esta exista es necesaria la participación de un privado corruptor, y este también debe ser sancionado y condenado en un proceso penal, pues comete delito tanto el funcionario que recibe la dádiva como el particular que la ofrece, de tal manera, que se refuerzan las bases de un sistema más coherente e integral, en donde no solo se persiga al público sino también al particular.

\section{CONCLUSIONES}

El caso mencionado en el presente texto resulta relevante por ser uno de los primeros frutos de los esfuerzos de implementar un régimen sancionatorio en contra de los actos de corrupción en la función pública costarricense, que tal y como se menciona en el texto, ha sido producto de varios años de trabajo y cambios normativos y estructurales.

Estas iniciativas han conllevado la aprobación de normativa interna y refuerzo de instituciones públicas para que desempeñen mejor esta función, entre ellas la Contraloría General de la República, a fin de que pueda actuar no solo en el ámbito preventivo sino también en la investigación, y poder acudir a instancias judiciales cuando producto de esa labor de investigación encuentre situaciones que ameriten la sanción penal contra un funcionario y un particular.

Dentro de los aspectos destacados de la sentencia 877-2011 están: respaldo de la capacidad jurídica de la Contraloría General de la República de Costa Rica para acudir y actuar en un juicio penal, lo cual es un cambio de mentalidad relevante, pues anteriormente el órgano contralor era un mero asesor o colaborador de la Procuraduría General de la República, institución que tenía la representación judicial del Estado y era la única que podía actuar en juicio. A partir de la interpretación actual del régimen jurídico, se rompe con este rol pasivo o de mero colaborador y se le otorga un papel predominante al órgano contralor para el ejercicio activo de sus potestades de control y fiscalización de la Hacienda Pública, de tal manera que cuando producto del ejercicio de sus potestades constitucionales encuentre evidencia de la comisión de un delito penal, podrá acudir directamente a las instancias judiciales para que se sienten las responsabilidades penales que correspondan.

El papel de la prueba técnica contable. El presente caso tuvo como prueba fundamental para la demostración de los delitos imputados dos pruebas contables: a) el rastreo del origen de los pagos y b) el análisis de la capacidad económica del acusado. Ello refleja la importancia del papel del perito contable en la investigación y demostra- 
ción de este tipo de delitos, que si bien no son prueba directa, corresponden a prueba indiciaria que, unida a otros elementos probatorios recabados durante la investigación, le permiten al juez concluir con un grado de certeza razonable que se cometió un delito de corrupción. En el caso que nos ocupa, el alto grado de profesionalismo de los peritos contables del órgano contralor permitieron introducir dicha prueba a juicio, que sirvió de base para la condenatoria alcanzada.

Se logra la condenatoria por el delito de falsedad en la declaración jurada, en perjuicio del sano y normal funcionamiento de la administración pública, reforzando la importancia de este instrumento preventivo de la corrupción. El Tribunal condenó por la omisión en la declaración, señalando el deber de todo funcionario público de rendir una declaración completa, tanto en activos como en pasivos, y rechazando el argumento expuesto por la parte acusada de que dicha omisión era una mera falta administrativa o simple descuido, restándole importancia a este instrumento. Por el contrario, el Tribunal considera que esta herramienta de lucha contra la corrupción es esencial para el adecuado funcionamiento del sistema, por lo que condena al imputado por la omisión en su declaración, aclarando que la misma no es una mera formalidad. Igualmente, se logra la condenatoria en los delitos de enriquecimiento ilícito y cohecho impropio en contra del funcionario público acusado, pero de mayor relevancia la condenatoria del delito de cohecho impropio en la modalidad de penalidad de corruptor contra el sujeto privado involucrado en los hechos. Lo expuesto resulta relevante pues todo acto de corrupción consta de dos actores: el funcionario público corrupto y el sujeto privado corruptor, de tal manera que una lucha efectiva contra la corrupción demanda que se investigue y sancione de igual forma a ambas partes, y no únicamente al funcionario público.

Como conclusión final, se debe destacar el hecho de ser la primera sentencia condenatoria de este tipo, siendo uno de los primeros frutos alcanzados en la lucha contra la corrupción en Costa Rica luego de las importantes reformas jurídicas e institucionales que ha tenido el país en los últimos años. Los cambios instaurados traerán otros casos y también nuevos retos, pero por el momento es el primer gran triunfo de la Contraloría General de la República en su papel de resguardo de la Hacienda Pública.

\section{BIBLIOGRAFÍA}

Opinión Jurídica: 107-J, 107 (Procuraduría General de la República 01 de agosto de 2005).

00827-2011,00827 (Sala Constitucional 25 de Enero de 2011).

00877-2011, 00877 (Sala Tercera de la Corte 22 de Julio de 2011). 
Arroyo Chacón, J. I. (2010). "Una definición de corrupción desde la Auditoría de la Ética”, en Revista de Expertos Iberoamericanos de Gestión Pública.

Arroyo Chacón, J. I. (2011). "Una definición de corrupción desde la Auditoría de la Ética", en Revista de Expertos Iberoamericanos en Fiscalización, 19-23.

Arroyo Chacón, J. I. (2013). "Marco jurídico y acciones establecidas en Costa Rica tendientes a la lucha contra la corrupción en la función pública", en Revista Judicial , 211-236.

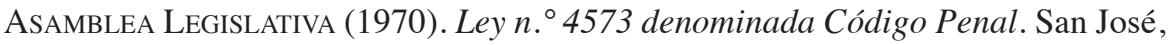
Costa Rica: SINALEVI.

Asamblea Legislativa (1994). Ley $n .^{\circ} 7428$ denominada Ley Orgánica de la Contraloría General de la República. San José, Costa Rica: Asamblea Legislativa.

Asamblea Legislativa (2002). Ley $n .^{\circ} 8242$ denominada Ley de Creación de la Procuraduría de la Ética Pública. San José, Costa Rica: Asamblea Legislativa.

Asamblea Legislativa (2004). Ley $n .^{\circ} 8422$ denominada Ley contra la Corrupción y el Enriquecimiento Ilícito en la Función Pública. San José, Costa Rica: Asamblea Legislativa.

Asamblea Legislativa (2006). Decreto Ejecutivo n. ${ }^{\circ} 33411$ denominado Reglamento a la Ley de Contratación Administrativa. San José, Costa Rica: SINALEVI.

Bolaños GonZÁlez, J. (2003). "El régimen jurídico de la denuncia como instrumento en la lucha contra la corrupción”, en P. G. República, Ley contra la Corrupción y el Enriquecimiento Ilícito en la Función Pública (pp. 230 a 239). San José, Costa Rica: PGR.

Bolaños GonzÁlez, J. (2010). "Los siete caldos de cultivo de la corrupción”, en Revista de Expertos Iberoamericanos en Gestión Pública .

Carbonell, M. y VÁzquez, R. (2003). Poder, derecho y corrupción. México: Instituto Federal Electoral.

Carvajal Ahumada, G. (2014). La corrupción en sus justas proporciones: Un ensayo de teoría sobre la corrupción administrativa. Ecuador, Quito: XIX Congreso Internacional del CLAD sobre la Reforma del Estado y de la Administración Pública.

Centro latinoamericano de administración para el Desarrollo (2003). Carta Iberoamericana de la Función Pública. Santa Cruz de la Sierra, Bolivia: Naciones Unidas. Departamento de Asuntos Económicos y Sociales. 
Comisión Técnica de Rendición de Cuentas (2007). Comisión Técnica de Rendición de Cuentas. XVII Asamblea General de la OLACEFS. Hacia la declaración de principios de rendición de cuentas. Santo Domingo, República Dominicana: OLACEFS.

CONTRAloría General de la República (2004). Resolución $n .^{\circ} D$-2-2004-Co denominada "Directrices generales sobre principios y enunciados éticos a observar por parte de los jerarcas, titulares subordinados, funcionarios de la Contraloría General de la República, auditorías internas y servidores públicos. San José, Costa Rica: Contraloría General de la República.

Contraloría General de la República (2012). Memoria Anual 2011. San José, Costa Rica: Contraloría General de la República.

Contraloría General de la República (2015). Memoria Anual 2014. San José, Costa Rica: Contraloría General de la República.

JiMmy, B. G. (2011). "La Contraloría General de la República. El perro guardián de la Hacienda Pública", en Revista de la Red de Expertos Iberoamericanos en Fiscalización, 30-35.

Malem SeÑA, J. (2002). La corrupción: Aspectos éticos, económicos, políticos y jurídicos. Editorial Gedisa.

Montero Traibel, J. (2013). El gobierno abierto como herramienta para la transformación del Estado en su lucha contra la corrupción. Uruguay: XVIII Congreso Internacional del CLAD sobre la Reforma del Estado y de la Administración Pública.

NAEssens, H. (2010). Ética pública y transparencia. México: Congreso Internacional 1810-2010: 200 años de Iberoamérica.

ORGANIZACIÓN DE ESTADOS AMERICANOS - OEA (1996). Convención Interamericana contra la corrupción de los países miembros de la Organización de Estados Americanos (OEA). Venezuela: OEA.

ORGANIZACIÓN DE LAS NACIONES UnIDAS (2005). Convención de las Naciones Unidas contra la Corrupción. New York, Estados Unidos: Secretaría de las Nacionas Unidas.

Organización Internacional de las Entidades Fiscalizadoras Superiores - INTOSAI (1977). Declaración de Lima. Lima: Organización Internacional de las Entidades Fiscalizadoras Superiores .

ORGANIZACIÓN INTERNACIONAL DE LAS ENTIDADES FISCALIZADORAS SUPERIORES (2007). ISSAI 10 - Declaración de México sobre Independencia de las EFS. México: INTOSAI. 
Organización Latinoamericana y del Caribe de Entidades de Fiscalización SUPERIOR - OLACEFS (2013). h. Declaración de Santiago sobre gobernanza, lucha contra la corrupción y confianza pública OLACEFS. Santiago, Chile: OLACEFS.

Poder Ejecutivo (2005). Decreto Ejecutivo 32333, denominado Reglamento de la Ley contra la Corrupción y el Enriquecimiento Ilícito en la Función Pública. San José, Costa Rica: Asamblea Legislativa.

Secretaría de la Contraloría y Transparencia Gubernamental (s.f.). Transparencia y rendición de cuentas: Conceptos y elementos básicos. México: Gobierno del Estado de Oaxaca.

Seijo SuÁrez, C. y AÑez Tellería, N. (2008). La gestión ética en la administración pública: base fundamental para la gerencia ética del desarrollo. Venezuela: Centro de Investigación de Ciencias Administrativas y Gerenciales. 